\title{
ANALISIS STRES KERJA PADA SATUAN POLISI PAMONG PRAJA DI KABUPATEN SUKOHARJO
}

\author{
Wartini $^{1}$, Titik Haryanti ${ }^{2}$ \\ Universitas Veteran Bangun Nusantara Sukoharjo \\ wartiniskm.msc@gmail.com, haryanti.titik@gmail.com ${ }^{1}$
}

\begin{abstract}
Work can give role of is necessary for human life. Work can give challenge and satisfaction, earn also become threat and trouble. Trouble factor health of the job effect not only physical factor but also psychological element. Increase of job stres quickly and can rising social impact, emotional, psychological and problem of related to health.Goal of research to analyse corelation among work load with job stres at Satuan Polisi Pamong Prajaat District of Sukoharjo. Type research of analytic observasional with approach of crossectional. Research population all satuan polisi pamong praja distric Sukoharjo and of sampel a number of 50 people with sampling technique of simple sampling random. this Research variable is work load (variable independent) and job stres ( variable dependent). data analysis use Product Moment Pearson. Result of research show work load of satuan polisi pamong praja is including moderate category counted 37 people ( $74 \%$ ) while job stres including light category counted 43 people ( $86 \%$ ) and there are corelation among work load with job stress at satuan polisi pamong praja Distric of Sukoharjo $\mathrm{p}=0,000$ $(\mathrm{p}<0,005)$.
\end{abstract}

Keyword : Job Stress, Workload

\begin{abstract}
ABSTRAK
Pekerjaan dapat memberikan peran penting bagi kehidupan manusia. Pekerjaan dapat memberikan kepuasan dan tantangan, dapat pula menjadi gangguan dan ancaman. Faktor gangguan kesehatan akibat kerja tersebut tidak hanya faktor fisik tetapi juga unsur psikologis. Peningkatan stres kerja dengan cepat dan dapat menimbulkan dampak sosial, emosional, psikologis dan masalah-masalah yang berhubungan dengan kesehatan. Tujuan penelitian unruk menganalisis hubungan antara beban kerja dengan stres kerja pada Satuan Polisi Pamong Praja Kabupaten Sukoharjo. Jenis penelitian observasional analitik dengan pendekatan crossectional. Populasi penelitian semua petugas satuan polisi pamong praja dan sampel sejumlah 50 orang dengan teknik sampling simple random sampling. Variabel penelitian ini beban kerja (variabel independent) dan stres kerja (variabel dependent). Analisa data menggunakan Product Moment Pearson. Hasil penelitian menunjukkan beban kerja satuan polisi pamong praja termasuk kategori sedang sebanyak 37 orang (74\%) sedangkan stres kerja termasuk kategori stres ringan sebanyak 43 orang (86\%) dan terdapat hubungan antara beban kerja dengan strs kerja pada satuan polisis pamong praja kabupaten Sukoharjo $\mathrm{p}=0,000(\mathrm{p}<0,005)$.
\end{abstract}

Kata Kunci : Stres Kerja, Beban Kerja

\section{PENDAHULUAN}

Pekerjaan dapat memberikan peran penting bagi kehidupan manusia. Pekerjaan dapat memberikan kepuasan dan tantangan, dapat pula menjadi gangguan dan ancaman. Gangguan kesehatan akibat lingkungan fisik sudah lama diketahui, seperti halnya desain dan organisasi kerja yang tidak sesuai kapasitas kerja, seperti kecepatan dan beban kerja yang berlebihan merupakan faktor lain yang dapat menimbulkan gangguan kesehatan akibat kerja. Faktor gangguan kesehatan akibat kerja tersebut tidak hanya faktor fisik tetapi juga unsur psikologis. Pekerjaan sendiri tidak selalu menjadi satu-satunya sumber penyebab gangguan psikologis, akan tetapi dapat mempengaruhi kerentanan individu terhadap kegagalan tertentu di lingkungan kerja yang penuh dengan stresor fisik. Stresor fisik di tempat kerja, seperti bising, penerangan yang kurang memadai, temperatur ruangan yang terlalu tinggi, serta bahaya-bahaya fisik lainnya (Harrianto, 2009). 
Intensifikasi pekerjaan pasti membawa konsekuensi bagi pekerja dengan memberikan tuntutan yang lebih besar pada kemampuan kognitif, psikologis dan fisik.Secara keseluruhan, konsekuensi psikologis dan fisik yang diamati pada pekerja adalah beban kerja, atau kelebihan beban kerja. Bekerja secara intensif dan konsekuensinya mempengaruhi sumber daya internal dan eksternal yang tersedia untuk pekerja dan manajemen dalam mengatasi kendala kerja. Hal ini pada gilirannya dapat menghasilkan sebuah rantai masalah di tempat kerja dan dalam kesehatan dan keselamatan pekerja (Fournier et al., 2011).

Kelebihan beban kerja akan tampak sebagai salah satu faktor risiko utama yang menyebabkan tekanan psikologis di tempat kerja. Lebih khusus lagi, konsekuensi dari intensifikasi pekerjaan yang berhubungan dengan berbagai masalah psikologis seperti stres kronis, kecemasan, depresi, gangguan psikosomatik, mekanisme dekompensasi psikologis, kecanduan kerja (gila kerja) dan kelelahan. Fenomena ini memiliki dampak meningkatkan konsumsi obat psikotropika ketika mencoba untuk mengatasi masalah psikologis mereka, juga tampak pada individu yang terkena jam kerja yang panjang akan memiliki kebiasaan gaya hidup tidak sehat (misalnya pola makan, merokok atau konsumsi alkohol) ( Fournier et al., 2011).

Penelitian yang dilakukan Ismar (2011) di perusahaan percetakan menyatakan sebanyak $18 \%$ pekerja mengalami stres berat, sedangkan penelitian Setyawan et al. (2008) sebesar $58 \%$ responden mengalami kecenderungan gejala gangguan mental emosional pada pekerja redaksi surat kabar di Jakarta. Fenomena stres kerja mengalami peningkatan dengan cepat dan dapat menimbulkan dampak sosial, emosional, psikologis dan masalah-masalah yang berhubungan dengan kesehatan.

Satuan Polisi Pamong Praja (Satpol PP) mempunyai tugas pokok menegakan peraturan daerah, menyelenggarakan ketertiban umum dan ketentraman masyarakat serta perlindungan masyarakat. Hasil wawancara dengan kepala dinas satuan polisi pamong praja menyatakan bahwa anggotanya sebanyak 114 orang dan di Kabupaten Sukoharjo seharusnya ada kurang lebih 300an orang, hal ini akan menambah beban kerja satuan polisi pamong praja menjadi overload. Anggota satpol pp bekerja kerasa akibat kurang mencukupi jumlah Satpol PP yang ada di sukoharjo sehingga seringkali mereka dihadapkan pada tuntutan kerja yang tinggi yang dapat menyebabkan stres kerja.

Dari latar belakang tersebut rumusan yang akan dibahas yaitu apakah ada hubungan antara beban kerja dengan stres kerja pada satuan polisi pamong praja di Kabupaten Sukoharjo?

\section{METODE}

Jenis penelitian adalah observasional analitik dengan pendekatan Cross Sectional. Populasi dalam penelitian ini adalah seluruh polisi pamong praja yang bekerja di kabupaten Sukoharjo sebanyak 114 orang. Teknik sampling dalam penelitian adalah simple random sampling diperoleh sampel sebanyak 50 orang (Setyawan dkk, 2008). Variabel yang diteliti pada penelitian ini adalah beban kerja (variabel bebas), dan stres kerja (variabel terikat). Beban kerja adalah tuntutan psikis, tuntutan fisik, tuntutan waktu, kinerja dan tingkat usaha yang dilakukan untuk melakukan pekerjaannya. Alat ukur yang digunakan dalam penelitian ini skala NASA TLX, skala berisi pertanyaan yang mengarah pada upaya psikis seperti tuntutan mental, tuntutan fisik, tuntutan waktu, kinerja, tingkat usaha yang dilakukan dan tingkat frustasi akibat pekerjaan yang dilakukan. Skala terdiri dua tahap, tahap pertama responden diminta untuk memilih item yang berpasangan mana yang menyumbang beban kerja responden dalam melakukan pekerjaannya. Pada tahap dua adalah skala rating yaitu dengan memberikan skor terhadap item aktivitas psikis menurut persepsi responden. Variabel ini diukur dengan menggunakan skala yang diadopsi dari penelitian Simanjuntak (2010). Apabila hasil skor tinggi menunjukkan kategori beban kerja tinggi dan apabila skor rendah akan dikategorikan sebagai beban kerja rendah dengan menggunakan skala interval.

Stres kerja merupakan reaksi pekerja berdasarkan gejala psikis, fisiologis dan perilaku. Variabel ini diukur dengan menggunakan skala general health questionnaire (GHQ) yang terdiri 28 item yang diadopsi dari penelitian Lesage (2011). Hasil skor tinggi menunjukkan stres kerja tinggi dan skor rendah menunjukkan stres kerja rendah dengan menggunakan skala interval. Alat yang dipakai untuk mengukur variabel dalam penelitian ini adalah skala. Skala digunakan 
untuk mengukur beban kerja dan tingkat stres kerja pada pekerja. Skala stres kerja diadopsi dari penelitian Lesage et al. (2011) sebagai alat pengumpul data berdasarkan pada gejala yang dapat ditimbulkan akibat stres yang berisi pernyataan yang bersifat unfavorable, menurut Rivai dan Mulyadi (2009) gejala stres dibagi menjadi 3 yaitu gejala psikologis, gejala fisiologis dan gejala perilaku. Skala beban kerja didasarkan pada tuntutan mental, tuntutan fisik, tuntutan waktu dan kinerja yang dilakukan pekerja dalam melakukan pekerjaannya. Setelah data responden lengkap dan dikumpulkan. Data dianalisis secara univariat dan bivariat dengan menggunakan uji Product Moment Pearson untuk mengetahui hubungan dua variabel beban kerja dengan kelelahan dan stres kerja.

\section{HASIL}

Satuan polisi pamong praja merupakan bagian dari pemerintahan dalam menegakkan peraturan daerah, penyelenggaraan ketertiban umum, serta ketentraman masyarakat. Tugas pokok Satpol PP adalah menegakkan perda dan menyelelnggarakan ketertiban umum serta ketentraman masyarakat dan perlindungan masyarakat. Fungsi Satpol PP : 1). Menyusun program dan melaksanakan penegakan perda, penyelenggara ketertiban umum dan ketentraman masyarakat serta melindungi masyarakat. 2). Melaksanakan kebijakan penegakan perda dan peraturan kepala daerah, 3). Melaksanakan kebijakan penyelenggaraan ketertiban umum dan ketentraman masyarakat di daerah, 4). Melaksanakan kebijakan perlindungan masyarakat, 5). Pelaksanaan koordinasi peraturan daerah, danpoeraturan kepala daerah, menyelenggarakan ketertiban umum dan ketentraman masyarakat dengan kepolisian negara Republik Indonesia, penyidik pegawai negeri sipil daerah atau aparatur lainnya, 6). Melaksanakan tugas lainnya yang diberikan oleh kepala daerah.

Wewenang Satpol PP: 1). Melaksanakan tindak penertiban non yudisial terhadap warga masyarakat, aparatur/badan hukum yang melakukan pelanggaran peraturan daerah atau peraturan keepala daerah, 2). Menindak warga/ masyarakat yang melanggar peraturan daerah atau peraturan kepala daerah, 3). Memfasilitasi dan pemberdayaan kapasitasi penyelenggaraan peraturan daerah, 4). Melakukan tindakan penyelidikan terhadap warga masyarakat, aparatur yang melakukan pelanggaran peraturan daerah, 5). Melakukan tindakan administratif terhadap warga masyarakat, aparatur yang melakukan pelanggaran peraturan daerah (PP no 6, 2010).

1. Karakteristik Pekerja

Tabel 1. Karakteristik Responden

Berdasarkan Pendidikan

\begin{tabular}{lcc}
\hline Pendidikan & Jumlah & $\begin{array}{c}\text { Persentase } \\
(\%)\end{array}$ \\
\hline SMA/SMK & 35 & 70 \\
D3 & 8 & 16 \\
S1 & 7 & 14 \\
\hline Jumlah & 50 & 100 \\
\hline
\end{tabular}

Tabel 2. Karakteristik Responden

Berdasarkan Umur

\begin{tabular}{lcc}
\hline Umur & Jumlah & Persentase (\%) \\
\hline $20-25$ & 10 & 20 \\
$26-30$ & 8 & 16 \\
$31-35$ & 32 & 64 \\
\hline Jumlah & 50 & 100 \\
\hline
\end{tabular}

Tabel 3. Karakteristik Responden

Berdasarkan Masa Kerja

\begin{tabular}{lcc}
\hline Masa Kerja & Jumlah & Persentase (\%) \\
\hline $1-6$ & 20 & 40 \\
$7-12$ & 25 & 50 \\
$13-18$ & 5 & 10 \\
\hline Jumlah & 50 & 100 \\
\hline
\end{tabular}

\section{Beban Kerja}

Tabel 4. Tabel Distribusi Frekuensi Beban Kerja Satpol PP Kabupaten Sukoharjo

\begin{tabular}{ccc}
\hline Beban Kerja & Frekuensi & $\begin{array}{c}\text { Persentase } \\
(\%)\end{array}$ \\
\hline Ringan & 7 & 14 \\
Sedang & 37 & 74 \\
Berat & 6 & 12 \\
\hline Jumlah & 50 & 100 \\
\hline
\end{tabular}

\section{Stres Kerja}

Tabel 5. distribusi frekuensi stres kerja Satpol PP Kabupaten Sukoharjo

\begin{tabular}{lcc}
\hline \multicolumn{1}{c}{$\begin{array}{c}\text { Stres } \\
\text { Kerja }\end{array}$} & Frekuensi & $\begin{array}{c}\text { Persentase } \\
(\boldsymbol{\%})\end{array}$ \\
\hline Ringan & 3 & 6 \\
Sedang & 43 & 86 \\
Berat & 4 & 8 \\
\hline Total & 50 & 100 \\
\hline
\end{tabular}

\section{Hubungan Beban kerja dengan stres kerja}


Tabel 6. Hubungan Beban Kerja dengan Stres Kerja

\begin{tabular}{lcccccc}
\hline Beban Kerja & \multicolumn{3}{c}{ Stres Kerja } & Total & rxy & p \\
\cline { 2 - 4 } & Ringan & Sedang & Berat & & & \\
\hline Ringan & 3 & 4 & 0 & 7 & & \\
Sedang & 0 & 36 & 1 & 37 & 0.674 & 0.000 \\
Berat & 0 & 3 & 3 & 6 & & \\
\hline Total & 3 & 43 & 4 & 50 & & \\
\hline
\end{tabular}

Karakteristik responden berdasarkan pendidikan $70 \%$ berpendidikan SMA/SMK, $64 \%$ berumur 31-35 tahun dan mayoritas dengan masa kerja 7-12 tahun (50\%). Sebagian besar responden mempersepsikan beban kerja sedang $(74 \%)$, dan $86 \%$ mempersepsikan stres kerja sedang. Tabel 6 dapat diketahui bahwa terdapat hubungan yang signifikan antara beban kerja dengan stres kerja ditunjukkan deng nilai $\mathrm{p}(0.000)$ dan hubungan dengan arah positip (0.674) antara beban kerja dengan stres kerja sehingga disimpulkan bahwa terdapat hubungan yang signifikan antara beban kerja dengan stres kerja pada satuan polisi pamong praja di Kabupaten Sukoharjo.

\section{PEMBAHASAN}

Responden sebagian besar (74\%) mempersepsikan beban kerja sedang, hal ini disebabkan karena sebagaian besar anggota Satpol PP sudah lama bekerja dengan masa kerja rata-rata lebih dari 1 tahun sehingga pekerjaan sudah menjadi rutinitas yang yang harus dilakukan dan sebagian besar anggota Satpol PP berusia produktif sehingga kapasitas kerja masih cenderung baik kekuatan ototnya (Tarwaka, 2011; Suma'mur, 1996). Stres keja dipersepsikan oleh anggota satpol pp sebagian besar (86\%) adalah stres kerja sedang, hal ini disebabkan usia yang matang akan berpengaruh terhadap pola pikir dan kedewasaan dalam menghadapi masalah sehingga akan berpengaruh terhadap kemampuan memecahkan masalah yang sedang dihadapi di lingkungan kerja (Smet, 1994). Dukungan sosial juga akan mempengaruhi individu dalam menghadapi masalah yang sedang dihadapai, hubungan personal dan sosial yang baik diantara anggota satpol pp akan berpengaruh terhadap kondisi yang penuh dengan stres sehingga akan mengurangi beban psikologis yang dialami anggota satpol pp (Direktorat bina kesehatan kerja dan olah raga, 2011). Massa kerja yang cukup lama (> 1 tahun) memungkinkan anggota satpol pp sudah menguasai job deskripsi dengan baik sehingga akan akan memiliki mekanisme koping yang lebih baik. Hal ini sesuai dengan pendapat Fitri (2013) bahwa usia dan lama kerja akan mempengaruhi pengalaman dalam bekerja dan kemampuan mengatasi masalah yang ada di tempat kerja.

Hasil uji Productmomment Pearson antara beban kerja dengan stres kerja pada tabel 6 dapat diketahui bahwa nilai signifikansi (p) 0.000 . Hal ini menunjukkan hubungan antara beban kerja dengan stres kerja signifikan, artinya beban kerja berkorelasi dengan stres kerja pada anggota satuan polisi pamong praja. Hal ini sejalan dengan penelitian Haryanti, dkk (2013) bahwa beban kerja berhubungan dengan stres kerja pada perawat. Beban kerja fisik dan psikis harus disesuaikan dengan kemampuan kerja dengan menghindarkan adanya beban berlebihan ataupun yang terlalu ringan (Sauter et al., 1990). Stres ringan atau sedang biasanya tidak memberikan terhadap prestasi kerja baik secara individu maupun organisasi ( Arifin R, dkk, 2003).

Tingkat beban kerja optimum dapat dicapai apabila tidak ada tekanan dan ketegangan yang berlebihan baik secara fisik dan mental (Tarwaka, 2011). Stres kerja dapat disebabkan oleh faktor lingkungan dan faktor personal. Faktor lingkungan fisik berupa kondisi fisik, manajemen kantor maupun hubungan sosial di lingkungan kerjanya, sedangkan faktor personal diantaranya adalah tipe kepribadian, peristiwa pribadi dimana pribadi masih dalam pengembangan diri. Anggota satpol pp sebagian besar berusia produktif sehingga lebih baik dalam mencari pemecahan masalah di tempat kerja, hal ini sesuai dengan hasil penelitian HSE (2005) bahwa mayoritas kasus yang berhubungan dengan kesehatan mental lebih didominasi oleh pekerja dengan usia 45-54 tahun dibandingkan dengan usia 35-44 tahun.

Individu mempunyai keyakinan bahwa mereka dapat mempengaruhi lingkungan kerja sekitar melalui apa yang mereka lakukan dan bagaimana mereka melakukannya, hal ini disebabkan mereka mempunyai locus of 
control terhadap lingkungan kerjanya (Wijono, 2011). Pekerja yang mempersepsikan beban kerja sedang dan stres sedang belum berpengaruh terhadap kinerja karena para anggota Satpol pp masih bersusia muda, dukungan sosial yang baik diantara anggota satpol pp dan mempunyai locus of control yang dapat mengurangi kecemasan akibat tuntutan kerja. Stres ditentukan oleh individu itu sendiri, sejauh mana ia melihat sebagai situasi yang penuh stres. Reaksi psikologis, fisiologis atau dalam bentuk perilaku stres adalah hasil dari interaksi situasi dengan individu mencakup ciri kepribadian khusus dan pola-pola perilaku yang didasarkan pada sikap, kebutuhan, nilai-nilai, pengalaman masa lalu, keadaan kehidupan dan kecakapan (intelegensi, pendidikan dan latihan) (Smet, 1994).

\section{SIMPULAN}

Terdapat hubungan antara beban kerja dengan stres kerja pada Satuan Polisi Pamong Praja di Kabupaten Sukoharjo yang ditunjukkan nilai signifikansi (p) 0.000 dan r 0.674

\section{DAFTAR PUSTAKA}

Arifin, R., Amirullah, Fauziah, S. 2003. Perilaku Organisasi. Malang: Bayumedia.

Christensen, E.H. 1991. Physiology of Work.Encyclopedia of Occupational Health and Safety. Third edt. Jenewa. ILO

Direktorat Bina Kesehatan Kerja dan Olah Raga.2011. Gangguan Kesehatan Akibat Faktor Psikososial di Tempat Kerja. Jakarta: Kementrian Kesehatan Republik Indonesia.

Fournier Sebastien, P, Montreuil, S, Brun Pierre,J, Bilodeauo,C,Villa, J. 2011. Exploratory Study to Identify Workload Factors that Have an Impact on Health and Safety. A Case Study in the Service Sector. Quebec: West Montreal.

Fitri. 2013. Analisis Faktor-faktor yang Berhubungan dengan Kejadian Stres Kerja pada Karyawan Bank (Studi pada
Karyawan Bank BMT). Jurnal Kesehatan Masyarakat Vol.2 No.1

Harrianto. 2009. Buku Ajar Kesehatan Kerja, Jakarta: EGC.

Haryanti, Aini, F., Purwaningsih, P. 2013. Hubungan Antara Beban Kerja Dengan Stres Kerja Perawat Di Instalasi Gawat Darurat RSUD Semarang. Jurnal Manajemen Keperwatan Vol 1 no 1.

Health Safety Exsecutive (HSE). 2005. Stress at Workplace. Avalaible in www.hse.org [Accessed 29 Juni 2013]

Ismar, R., Amri, Z., Sostrosumihardjo, D. 2011. Stres Kerja Dan Faktor Yang Berhubungan Pada Pekerja Call Center PT. X di Jakarta. Majalah Kedokteran. Vol. 1 .

Karwowski, W. 2006. Fundamental And Assessment Tool For Occupational Ergonomics. USA: CRC Press.

Lesage, F.X, Resende, S.M, Deschamp, F, dan Barjot, S. 2011. Validation Of The General Health Questionnaire Adapted To Work-Related Context. OJPM. Vol.1 no.2.

Nurmianto, E. 1996. Ergonomi Konsep Dasar dan Aplikasinya. Jakarta: Guna Widya.

Peraturan Pemerintah No 6 . 2010. Satuan Polisi Pamong Praja. Jakarta

Rivai, V., dan Mulyadi, D. 2009. Kepemimpinan Dan Perilaku Organisasi.edisi ke-3. Jakarta: Rajawali Pers.

Sauter, S.L., Murphy, L.R. and Hurrel, J.J. 1990. A National Strategy for the Prevention of Work-Related Psychological Disorders. American Psicologys.

Setyawan, Y.Z., Amri, Z., Sostrosumihardjo, D. 2008. Stres Kerja dan Kecenderungan Gejala Gangguan Mental Emosional Pada Karyawan Redaksi Surat Kabar ' $X$ ' di Jakarta. Majalah Kedokteran Indonesia.Vol. 58. 
Jurnal Manajemen Informasi dan Administrasi Kesehatan (J-MIAK)

Volume 01, No 01, Tahun 2018

ISSN: 2621-6612

Email:d3perinfokesunivet@gmail.com

Halaman: 49-54

Smet, B. 1994. Psikologi Kesehatan. Jakarta: Grasindo

Simanjuntak, R.A. 2010. Analisis Beban Kerja Mental dengan Metoda NASA TLX.

Jurnal teknologi technocientia. Vol.3.

Suma'mur, PK. 1996. Higiene Perusahaan dan Kesehatan Kerja. Jakarta: Gunung Agung.

Tarwaka, Bakri, AH,S., dan Sudiajeng, L. 2004. Ergonomi Untuk Kesehatan, Keselamatan dan Produktivitas. Edisi 1. Surakarta: Uniba Press.

Tarwaka. 2011. Ergonomic Industri. Dasar-Dasar Pengetahuan Dan Aplikasi Di Tempat Kerja. Edisi 1. Surakarta: Harapan Press.

Wijono, S. 2011. Psikologi Industri dan Organisasi. edisi 1. Jakarta: Fajar Interpratama Offset. 